\title{
Development of Getting Up Detection and Report Device using Power Line Communication and Mat-Sensor
}

\author{
Kazuo Haruyama Member (Ube National College of Technology, haruyama@ube-k.ac.jp) \\ Kanya Tanaka Senior Member (Yamaguchi University, ktanaka@eee.yamaguchi-u.ac.jp) \\ Shigeki Kobayashi Member (Viste Co., Ltd., skoba@viste.com) \\ Katsunori Yasuoka Non-member (Excel Engineering Co., Ltd., yasuoka@excel-jpn.com) \\ Akihiko Uchibori Member (Ube National College of Technology, uchibori@ube-k.ac.jp) \\ Masato Oka Member (Ube National College of Technology, oka@ube-k.ac.jp)
}

Keywords: power line communication, mat-sensor, getting up detection

\section{Background}

In Facilities for Elderly People and the Disabled, patient's safety control becomes a big problem. Then, various devices for the patient's safety confirmation are proposed. However, most devices need a special sensor and report devices. Special construction might be necessary expertise for operating and using the device.

\section{Abstract}

In this paper, we propose the getting up detection and report device which can be installed in middle-small facilities and ordinary houses. This device combines a mat sensor which detects rising and a power line communication (PLC) device as a reporting system. This device does not need any additional construction for installation as long as facilities equip electric power supply $100 \mathrm{~V}$ for ordinary businesses. At first, the mat sensor in the system detects rising of an elderly person or lying down to bed. The PLC system sends ON/OFF signal and reports to nurses and staff members in their rooms. Since the main objective of the PLC system is to keep exact detection and transmission of the mat-sensor ON/OFF signal, high-speed network is not necessary. It is required that the system should be robust against noises of household electrical appliances. We used the selected-career method as a transmission method in which we located 2 lines of tone frequency $(132 \mathrm{kHz}$ or $115 \mathrm{kHz})$ for the power line transmission in the device. The effectiveness of the proposed device has been confirmed by the field experiments in welfare facilities for elderly people.

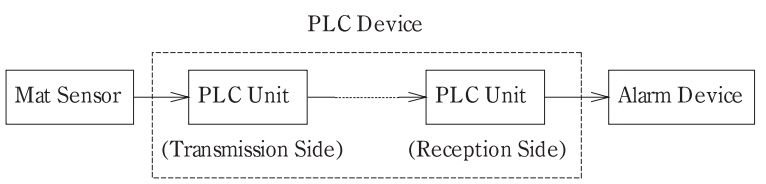

Fig. 1. Getting Up Detection and Report Device

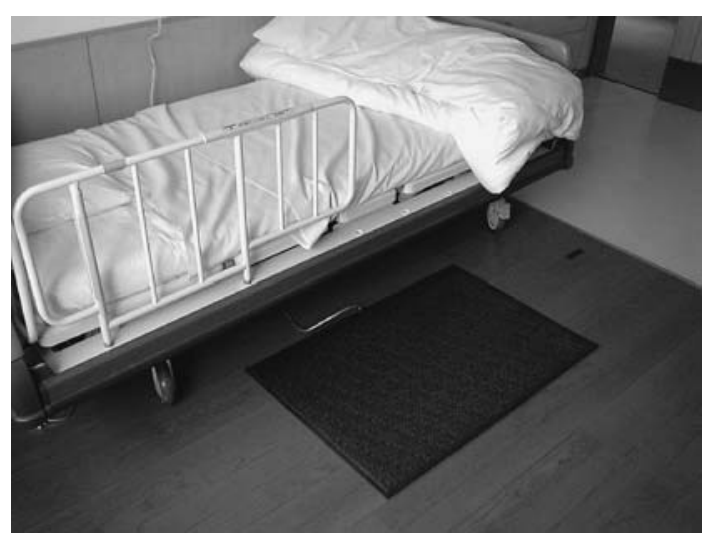

Fig. 2. Mat Sensor

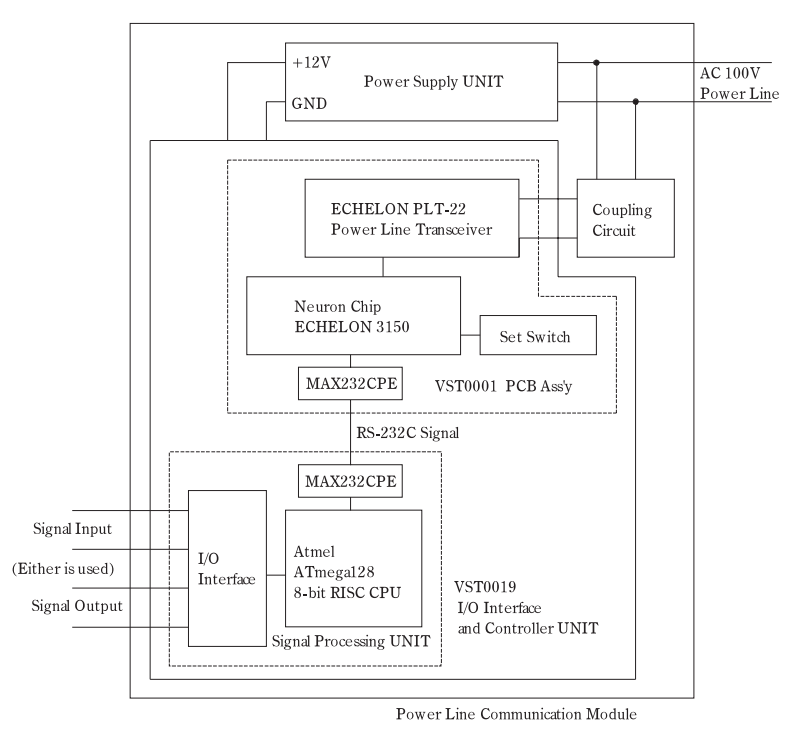

Fig. 3. Power Line Communication Modem 


\title{
電灯線通信とマット・センサーを用いた離床検知通報装置の開発
}

\author{
正 員 春山 和男 ${ }^{*}$ 上級会員 田中 幹也** \\ 正 員 小林 茂樹*** 非会員 安岡 克典**** \\ 正員 内堀 晃彦* 正 員 岡 正人*
}

\section{Development of Getting Up Detection and Report Device using Power Line Communication and Mat-Sensor}

\author{
Kazuo Haruyama*, Member, Kanya Tanaka**, Senior Member, Shigeki Kobayashi***, Member,

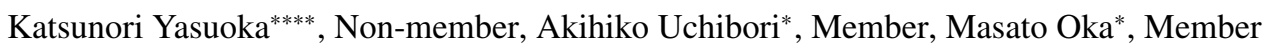

In this paper, we propose the getting up detection and report device which can be installed in middle-small facilities and ordinary houses. This device combines a mat sensor which detects rising and a power line communication (PLC) device as a reporting system. This device does not need any additional construction for installation as long as facilities equip electric power supply $100 \mathrm{~V}$ for ordinary businesses. At first, the mat sensor in the system detects rising of an elderly person or lying down to bed. The PLC system sends ON/OFF signal and reports to nurses and staff members in their rooms. Since the main objective of the PLC system is to keep exact detection and transmission of the mat-sensor $\mathrm{ON} / \mathrm{OFF}$ signal, high-speed network is not necessary. It is required that the system should be robust against noises of household electrical appliances. We used the selected-career method as a transmission method in which we located 2 lines of tone frequency $(132 \mathrm{kHz}$ or $115 \mathrm{kHz})$ for the power line transmission in the device. The effectiveness of the proposed device has been confirmed by the field experiments in welfare facilities for elderly people.

キーワード：電灯線通信，マット・センサー，離床検知

Keywords: power line communication, mat-sensor, getting up detection

\section{1. まえがき}

わが国では 1990 年代半ばに総人口に対する高齢者人口 の割合が $15 \%$ 越えいわゆる高齢化社会が到来した。その 後も高齢者人口は増加し続け，2020 年には 65 歳以上人口 は約 3,300 万人，高齢化率は少子化の影響もあり $26.9 \%$ に 達すると予測されている(1)。これに伴い 2000 年 4 月には介

\footnotetext{
*宇部工業高等専門学校

干 755-8555 宇部市常盤台 2-14-1

Ube National College of Technology

2-14-1, Tokiwadai Ube 755-8555

** 山口大学工学部

干755-8611 宇部市常盤台 2-16-1

Faculty of Engineering, Yamaguchi University

2-16-1, Tokiwadai Ube 755-8611

**** 有) ヴィスト

干 556-0005 大阪市浪速区日本橋 5-6-1 桃兵ビル 3F

Viste Co., Ltd.

5-6-1, Nihonbashi, Naniwa-ku, Osaka 556-0005

**** (株) エクセルエンジニアリング

厂 103-0022 東京都中央区日本橋室町 4-2-10 坂田ビル 5F

Excel Engineering Co., Ltd.

4-2-10, Nihonbashimuromachi, Chuo-ku, Tokyo 103-0022
}

護保健法も施行され，高齢者は一定の基準で看護・介護が 受けられる体制が整いつつある。同法の施行もあって最近 4 年間で高齢者用福祉施設数は約 5,290 施設, その利用者 数は約 36 万人へと急増している。一方, 高齢者の増加に伴 い認知症患者数も 160-180 万人と増加しており高齢者用福 祉施設等においては入居者の安全管理が大きな問題となっ ている。このため入居者の安否確認をするために様々な装 置が提案されている(2) (5)。しかしほとんどの装置は特別な センサーや通報装置を必要としており装置の操作に専門知 識が必要であったり，装置の導入に当たり特別な工事が必 要なものもある。これに対してマット・センサーとナース コールを組み合わせた離床検知通報装置は構造も簡単で安 価であり，看護師や介護者でも容易に取り扱えることから 最近需要が急増している ${ }^{\left({ }^{(}\right)}$。この装置は離床に伴う圧力変 化を検知するマット・センサーを認知症患者等のベッド上 やベッド横に設置し, 離床を検知するとナースコールを通し て看護師や介護者に通報する装置である。一方，最近では 高齢者用福祉施設は設備の整った大規模なものから 10-50 名を収容するグループ・ホーム（ハウス）などと呼ばれる 中小規模の施設が増加している。これらの中小施設ではほ 
Power Line Communication(PLC) Device

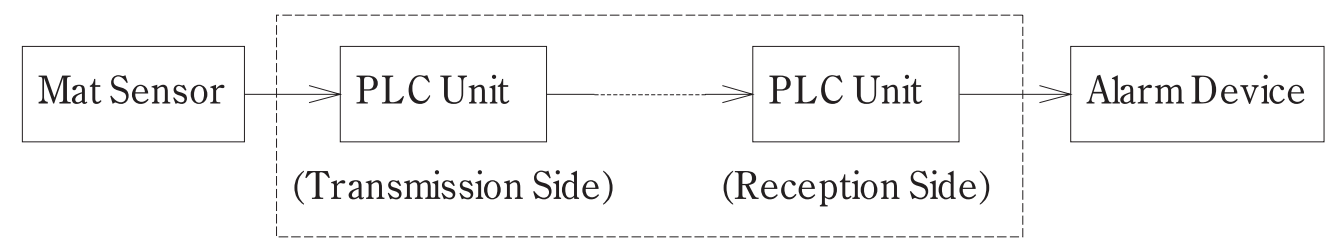

図 1 離床検知通報装置

Fig. 1. Getting Up Detection and Report Device.

とんどの場合ナースコール等は整備されていないのが現状 であり，このためナースコールの使用を前提とした前述の マット・センサー型離床検知通報装置を導入できないとい う問題点があった。

本論文ではナースコールの整備されていない中小高齢者 用福祉施設や一般家庭においても導入できる離床検知通報装 置を開発したので報告する。本装置は離床を検知するマッ ト・センサーと通報装置として電灯線通信装置を組み合わ せたもので，通常の商用電源 $(100 \mathrm{~V})$ を有する施設であれ ば装置の導入に当たって特別な工事を全く必要としない。 本装置では高齢者の起床あるいは着床動作により生起する マット・センサーの ON/OFF 信号 (電気抵抗值の変化) を電 灯線通信装置を用いて伝達・処理し管理室の看護師・介護者 に通報するものである。このため電灯線通信装置はマット． センサーの ON/OFF 信号を確実に検知し伝達することが主 目的であるため高速通信である必要はなく，それよりも電 灯線通信に影響を与える家電機器のノイズにロバストであ ることや現行法規に適合していることが必要である。この ため本装置の電灯線通信では 2 本のトーン周波数 $(132 \mathrm{kHz}$ および $115 \mathrm{kHz}$ ）を設置した選択型シングルキャリア方式で 2 相位相変調（BPSK）方式の通信方式を採用しており，現 行の電波法に適合して形式指定が受けられるものとなって いる。本装置の有用性は高齢者用福祉施設におけるフィー ルド試験によって検証されている。

本論文の構成は，以下の通りである。まず第 2 章では提 案する離床検知通報装置の概要を説明する。つづいて第 3 章では電灯線通信装置について述べる。第 4 章では本装置 の有用性を確認するために行ったフィールド試験の結果を 述べる。

\section{2. 離床検知通報装置の概要}

$\langle\mathbf{2} \cdot \mathbf{1}\rangle$ 装置の構成図 1 に提案する離床検知通報装 置の概要を示す。本装置はマット・センサー，電灯線通信 装置掞よび警報装置から構成される。マット・センサーは 図 2 で示すようにベッド脇の足元に敷いて使用する感圧導 電型センサーである。このセンサーに人が乗ると，その圧 力を感知して信号が発生し, 図 3 に示寸電灯線通信装置を 用いて図 4 に示す警報装置に通報される。電灯線通信装置 は一般の電灯線を使用して通信を行うための装置で，国内 の一般的な商用電源の単相 $100 \mathrm{~V} 50 / 60 \mathrm{~Hz}$ をはじめ電圧に

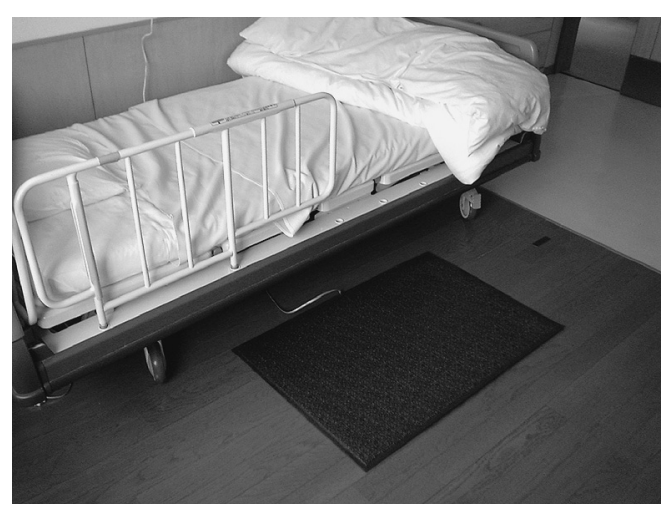

困 2 マット・センサー

Fig. 2. Mat Sensor.

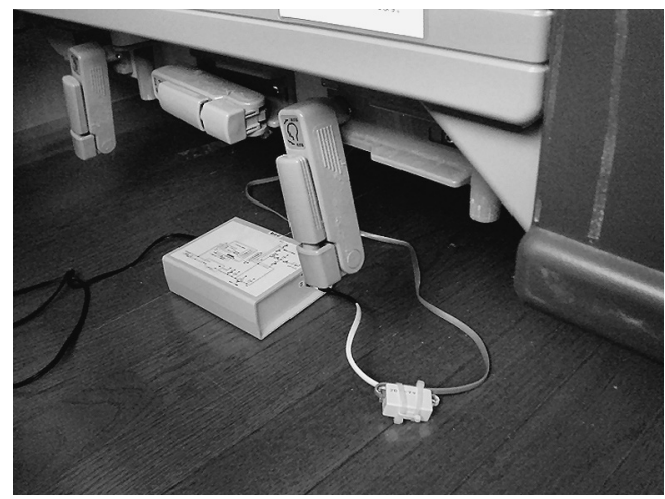

図 3 電灯線通信ユニット（送信側）

Fig. 3. PLC Unit (Transmission side).

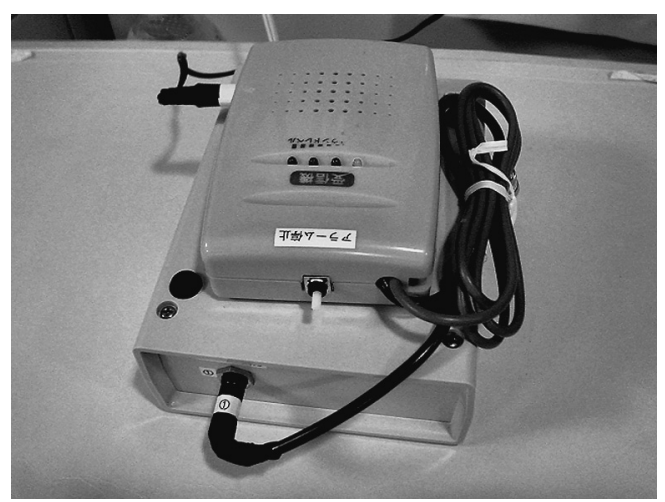

図 4 電灯線通信ユニット（受信側）と警報装置 Fig. 4. PLC Unit (Reception side) and Alarm Device. 

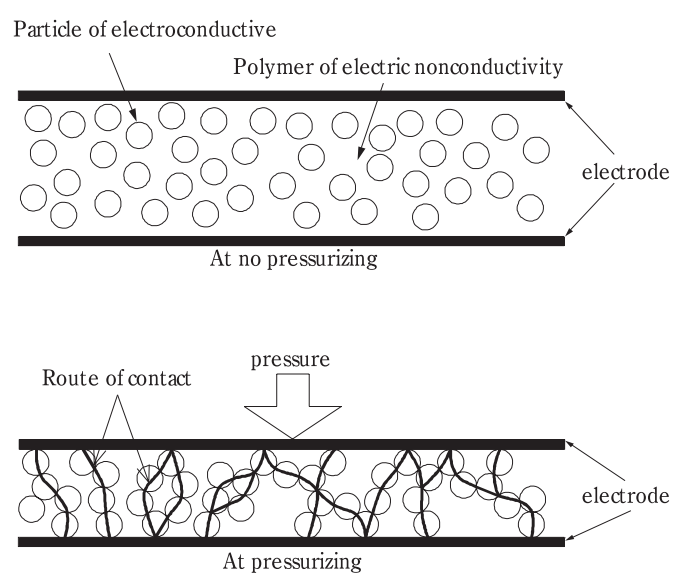

図 5 マット・センサーの信号発生原理

Fig. 5. Signal generation mechanism of a mat sensor.

関らず既設の電灯線を介して使用可能である。図 4 の警報 装置は，高齢者のマット・センサー上への着床を介護者に 知らせることを目的としている。

$\langle\mathbf{2} \cdot \mathbf{2}\rangle \quad$ マット・センサー マット・センサーは, 図 5 に示すようにゴム系材料中に導電性粒子がほぼ均等に分散 された状態で成形された素材の両面に電極を配したもので ある。無加圧時には導電性粒子が互いに非接触で導電経路 を形成しておらず，電気的に絶縁状態にある。これに加圧 すると導電性粒子同士が接触し導電経路が 3 次元的に形成 され，導通して電気抵抗がゼロの状態になる。無加圧状態 に戻すと, ゴム系材料の弾性による復元力によって導電性 粒子同士が非接触状態に戻り, 絶縁状態に戻る。外形サイ ズは $90 \times 60 \mathrm{~cm}$, 本体にマイコンや電子回路を内蔵してい ないためセンサーの最大厚みは数 $\mathrm{mm}$ と従来品に比べて非 常に薄く，使用に際し電源が不要であることが特徴である。 敷く床の材質にも場所にも影響されず，設置の際のキャリ ブレーション等も一切不要で非常に取り扱いが容易であり, 継続して使用する際に特別なメンテナンスも必要ない。

$\langle\mathbf{2} \cdot \mathbf{3}\rangle$ 警報装置 警報装置は, マットセンサーで発 生した ON 信号を電灯線装置を介して受信し，ブザーを鳴 らして警報を発する。センサーが作動してブザーが鳴り始 めると、リセットボタンを押さない限り鳴り続ける。

\section{3. 電灯線通信装置}

$\langle\mathbf{3} \cdot \mathbf{1}\rangle$ 装置の概要 電灯線通信は，我が国では電波 法上の “高周波利用設備のひとつである電力線搬送の通信 設備”と規定されている。この設備は無線局など他の通信 設備等に混信等を与えないように，設置にあたっては指定 されたものを除き，原則許可制になっている。指定された 設備とは, 電波法施工規則第 46 条の 2 に沿うもので, 使用 するトーン周波数, 変調形式, 通信速度などが細かく規定 されている。この条件にあてはまるものであれば総務大臣 に申請し形式指定を受けることで個別に許可を受けずに設 置・運用することができる。本装置はこの条件を満たすよ

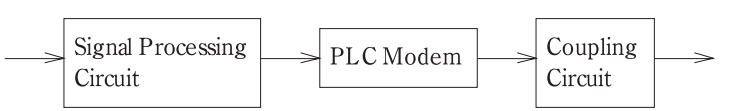

図 6 電灯線通信ユニット

Fig. 6. PLC Unit.

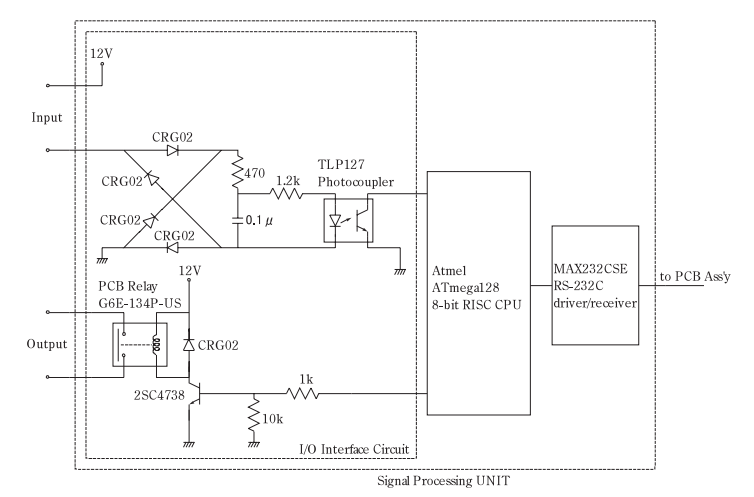

図 7 入出力信号処理回路

Fig. 7. I/O Signal Processing Circuit.

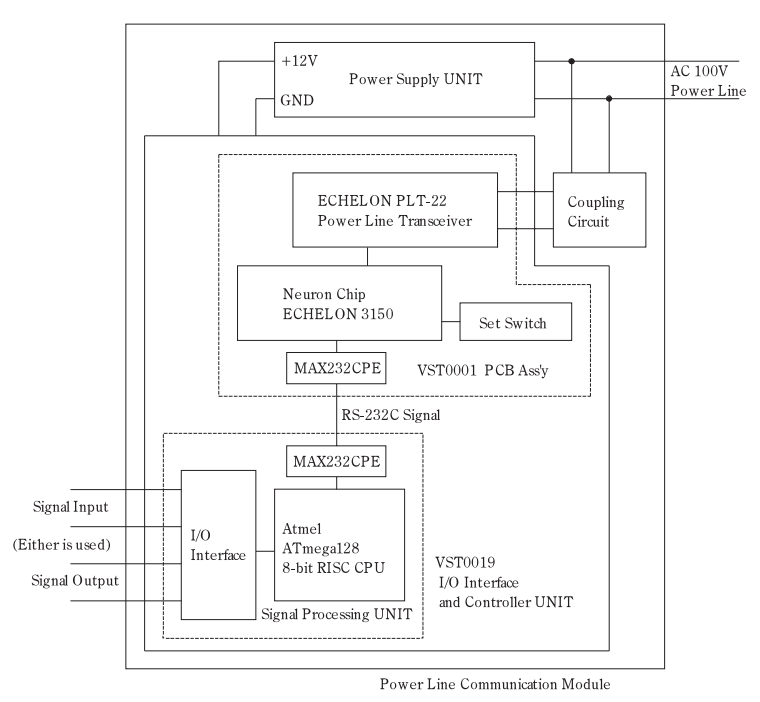

図 8 電灯線通信モデム

Fig. 8. PLC Modem.

う設計されており，図 6 に示すように入力信号や出力信号 を取り扱う入出力信号処理回路と, そこからの信号を電灯 線を用いて通信する電灯線通信モデムおよび電灯線との結 合回路から構成される。

〈3.2 入出力信号処理回路 入出力信号処理回路を 図 7 に示す。本装置のマット・センサーの ON/OFF 信号 は抵抗值の変化として表れる。センサーが圧力を感知する と絶縁状態から導通状態になり, 抵抗值がゼロになる。そ れが入力信号回路のフォトカプラを動作させ，ワンチップ マイコンの入力端子の電圧レベルが High から Low レベル へと変化する。ワンチップマイコンはこの信号を感知する と, 動作信号を出力する。装置では送信機と受信機が 1 対 1 の構成であることと後段の電灯線通信モデムに固有の ID が付与されているため，動作信号に子機の個体識別符号は 


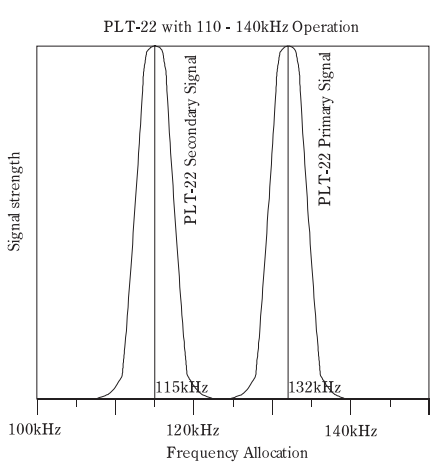

図 9 周波数割当

Fig. 9. Frequency Allocation.

不要で単にセンサー作動/終了（ON/OFF）を識別できれば よい。よって，センサー作動開始時抢よび作動終了時にア スキーコードで 1 文字 “A” と出力・認識させている。この 段階での信号は，信号パターンはデータビットにスタート ビットやストップビットが付加された RS232C 規格である が，電圧レベルは‘ 1 ’が+5V，“0’が $0 \mathrm{~V}$ の TTL レベルの ままなので, 後段の TTL-RS232C レベルコンバータ ICで ‘ 1 ’が-12V，'0’が+12V の RS232C レベルの信号にコン バートして電灯線通信装置へ出力している。この区間の信 号の伝送速度は $2,400 \mathrm{bps}$ である。

電灯線通信装置間で送受信される信号は，マット・セン サーからの作動を示す動作信号と電灯線通信装置によって 付加される子機の個体識別符号 (ID 番号) とが組み合わさ れて構成されており，親機では自分自身とペアである子機 を識別して動作する。

受信機側では送信機側からの信号を受信すると，受信し ている間ワンチップマイコンが出力回路のリレーを動作さ せ続け，その間警報装置として接続されたブザーが作動し 続ける。

〈3·3〉電灯線通信モデム＼cjkstart本装置は RS232C 信号を 電灯線を用いて送受信するもので, 図 8 に示すように入出力 用 RS232C レベルコンバータ IC, Neuron Chip, 電灯線通信 トランシーバユニットから構成される。電灯線通信モデム への入力信号は, RS232C レベルコンバータ ICで RS $232 \mathrm{C}$ レベル信号から TTL レベル信号に変換され，Neuron Chip に入力される。Neuron Chip は Echelon 社製 3150, 電灯 線通信トランシーバユニットは同社製 PLT-22 を使用した。 両者はぺアで使用することを前提に設計された専用品で, Neuron Chip は内蔵されたアプリケーションCPU，ネット ワーク CPU，メディアアクセス CPU の 3 つの CPU がパ イプライン動作している。この Neuron Chip は電灯線通信 トランシーバユニットの持つ ROM に書込まれたプログラ ムにより制御されている。また，ANSIにより制御ネット ワークの標準規格 EIA/CEA-709.1-A-1999 として認定され たオープンプロトコルである Lonworks が実装されている。 これは国際標準化機構（ISO）による通信モデル（OSI）の 7 層基本参照モデルに準拠しており，この 7 層全てのサー
ビスを提供している。設定スイッチによって与えられる ID 番号が付与された入力信号は，この規格に沿った Lontalk ネットワークプロトコル信号に変換され, 電灯線を通じて 送受信される。信号に ID 番号が含まれるため, 同時に 127 台までの本モデムを使用することが可能で，その場合でも どのモデムからの信号であるか容易に識別可能である。こ のユニットの最大通信速度は $5,400 \mathrm{bps}$ で, 変調方式は 2 相 位相変調（Binary Phase Shift Keying：BPSK）方式である。 パケット通信方式で，ノイズ等による通信途絶を避けるた め図 9 に示すように $132 \mathrm{kHz}$ (プライマリ) と $115 \mathrm{kHz}$ (セ カンダリ）の 2 つの周波数を自動的に切り替えて通信を行 う選択型シングルキャリア方式を採用している。これは両 周波数を同時に使用するのではなく，通常はプライマリ周 波数が使用され，雑音などで通信途絶状態になると自動的 にセカンダリ周波数に切り替えて動作する。具体的にはプ ライマリ周波数でパケットを 3 度送っても通信が確立され ない場合にはセカンダリ周波数に切り替えてパケットを 2 度送信する。これらの間に通信が接続されればその周波数 で送信される。このように，同一系統内に接続されている 家電製品の電源の $\mathrm{ON} / \mathrm{OFF}$ 等によるパルス的なノイズに対 しては特に強いシステムとなっている。

電灯線通信モデムと電灯線は, 図 10 に示すと打り電灯 線通信用パルストランスを用いた結合回路で結合されてい る。結合回路には，落雷などの過電流から回路を保護する ためのサージ・アブソーバーとヒューズからなる保護回路 も内蔵されている。

〈注意〉

電灯線通信方式としては他にスペクトル拡散方式や OFDM 方式等様々な方式があるが，これらを採用しなけ れば得られないような通信速度や通信デー夕容量は本装置 ではオーバースペックであり，さらにこれらの方式を採用 したのでは構造が複雑になり過ぎてコストパフォーマンス も悪いという判断から採用しなかった。

\section{4. フィールド試験}

〈4・1 フ フィールド試験の条件・方法 本装置の有用性 を検証するためにフィールド試験を実施した。試験は，「む 


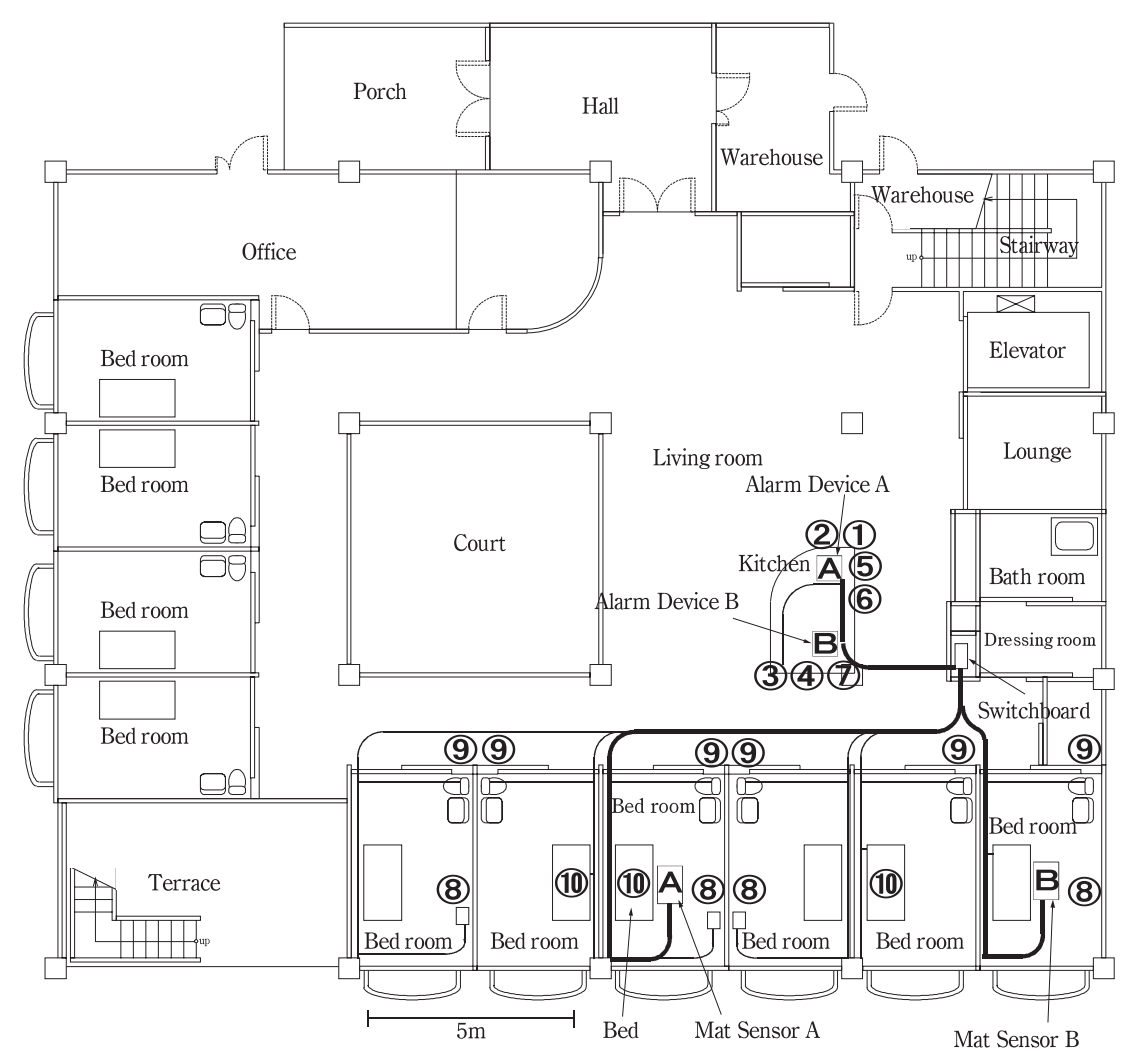

図 11 施設の配置図

Fig. 11. Arrangement chart of the facility.

べの里 特別養護老人ホーム (山口県宇部市)」の協力を得 て行った。むべの里は，平成 8 年 5 月に開設された収容人 数 84 名の中規模施設である。図 11 に同施設の試験を行っ たフロアの配置図を示す。図中の A， B がベッド・ルーム に設置されたマット・センサーで，それぞれに対応した警 報装置をキッチンカウンターに設置した。ベッド・ルーム の電灯線通信モデムはそれぞれ室内のコンセントに接続し た。マット・センサーと警報装置の直線距離は各々約 $10 \mathrm{~m}$ であるが，両者間の電灯線配線（図中の太い実線）は各々 約 $20 \mathrm{~m}$ と約 $15 \mathrm{~m}$ であり, 配電盤を介して継っている。本 施設での配電盤からの同一系統の電灯線は複数に分岐して おり，そのうち今回機材を設置した部分（図中の細い実線） には，多数の家電機器 (図中の丸付数字) が接続されてお りこれらを表 1 にまとめて示した。装置の適用者は入居中 の被験者（女性 2 名, 両者とも 86 歳) で, 試験は当該被 験者よりインフォームドコンセントを得て行った。実施期 間は, 平成 17 年 7 月 11 日から 24 日までの 2 週間と平成 17 年 12 月 19 日から平成 18 年 1 月 1 日までの 2 週間との 2 回である。1 回目の試験では A のセンサーだけを, 2 回 目の試験では A， B 両方のセンサーを同時に使用して試験 を行った。装置はこの間毎日夕食後 19 時より翌朝 7 時ま での間，夜間の介護者の人数が少なくなる時間帯にその補 助用として使用された。試験は, 本装置の警報が鳴る度に, 介護者が被験者の状態を確認し記録する方法で実施した。

$\langle\mathbf{4} \cdot \mathbf{2}\rangle$ 試験結果＼cjkstart試験結果を表 2 と表 3 に示す。 1 回
表 1 家電機器

Table 1. Household electrical appliances.

\begin{tabular}{|c|c|c|}
\hline No. & Article & Amount \\
\hline 1 & Personal Computer & 1 \\
\hline 2 & $\begin{array}{c}\text { Combination tape } \\
\text { recorder and radio }\end{array}$ & 1 \\
\hline 3 & Rice Cooker & 1 \\
\hline 4 & Dish washer & 1 \\
\hline 5 & Microwave oven & 1 \\
\hline 6 & Refrigerator & 1 \\
\hline 7 & Ventilation fan & 1 \\
\hline 8 & Television & 4 \\
\hline 9 & Toilet & 6 \\
\hline 10 & Electric bed & 3 \\
\hline & Total & 20 \\
\hline
\end{tabular}

表 2 試験結果 1

Table 2. Experimental results No.1.

\begin{tabular}{|c|c|}
\hline Date & $\begin{array}{c}\text { Alarm } \\
\text { frequency }\end{array}$ \\
\hline 2005.7 .14 & 3 \\
\hline 2005.7 .16 & 2 \\
\hline 2005.7 .17 & 1 \\
\hline 2005.7 .19 & 1 \\
\hline 2005.7 .21 & 2 \\
\hline 2005.7 .22 & 2 \\
\hline
\end{tabular}

\section{表 3 試験結果 2}

Table 3. Experimental results No.2.

\begin{tabular}{|c|c|c|}
\hline \multirow{2}{*}{ Date } & \multicolumn{2}{|c|}{ Alarm frequency } \\
\cline { 2 - 3 } & Sensor A & Sensor B \\
\hline 2005.12 .19 & 5 & 1 \\
\hline 2005.12 .20 & 1 & 1 \\
\hline 2005.12 .23 & 0 & 1 \\
\hline 2005.12 .24 & 1 & 0 \\
\hline 2005.12 .26 & 0 & 1 \\
\hline 2005.12 .30 & 5 & 0 \\
\hline
\end{tabular}

目の試験期間中に計 11 回，2 回目の試験中に計 16 回警報 装置のブザーが鳴り, その度介護者が被験者のもとに駆け つけたところ，いずれの場合も被験者がマット・センサー 上に着床していることが確認された。合計 4 週間の試験実 施期間中に，着床していないのに報知した誤報や，着床を 報知しない未検知は一度も生じなかった。また，本装置と 同一の電灯線上に一般家庭用の洗濯機や冷蔵庫など電源の ON/OFFによる負荷変動が大きい機器や TV やパソコンと いった電圧のピーク時に電力を消費する機器など 20 台の電 気機器が接続されており, これらが日常的に使用されてい たが，これらの機器の動作状態に関らず，相互の障害は一 切確認されなかった。以上のフィールド試験から, 本装置 の一般家庭や施設における有用性を確認することができた。 


\section{5. あとがき}

本論文では，ナースコール設備のない中小規模の高齢者 用福祉施設や一般家庭で使用することを目的とした電灯線 通信とマット・センサーを用いた離床検知通報装置を提案 した。本装置の有用性は，小規模福祉施設における 4 週間 にわたるフィールド試験において検証されている。今後わ が国の高齢者数は増加する一方であり，高齢者の収容施設 が中小規模の福祉施設や一般家庭が主体にならざるを得な いことを考慮すると既存の電灯線を用いて安価に導入でき る提案装置の有用性は明白である。

\section{謝 辞}

本研究はむべの里特別養護老人ホームの全面的な協力を 得て行った。ここに謝意を表する。

(平成 17 年 9 月 21 日受付，平成 18 年 6 月 1 日再受付)

\section{文献}

（1）大臣官房統計情報部企画課情報企画室：「厚生白書平成 12 年版」, 厚 生白書平成 12 年版 $(2000)$

（2）古川 聡・松田啓史・萩尾健一·谷口 良・筒井譲二・田中智幸:「ケ アモニタ向けセンサの検知技術」,松下電工技報 (Feb.2001), pp.16-22 (2001)

（3）川崎重工業：「介護支援システム」, 産業機械, No.611, pp.63-65 (2001)

(4) 古川 聡: 「画像処理技術による高齢者介護用振舞い検知システム」, 信学誌, Vol.85, No.4, pp.282-284 (2002)

（5）米沢良治・宮本泰彰・小川英邦・槙 弘倫 - 二宮石雄 - 佐田孝治 · 浜田真悟：「病院，福祉施設における新しい患者行動モニタリンク システム」, 医科機器学, Vol.72, No.9, pp.429-434 (2002)

（6）財団法人保健福祉広報協会：2004 年度版福祉機器カタログ, 第 31 回 国際福祉機器展最新福祉機器カタログ集 (2004)

\section{付 録}

\section{電灯線通信装置への家電機器のノイズの影響}

家電機器から発生するノイズについて検討するため, 代 表的な家電製品において交流 1 サイクル内の時間領域での 消費電力の分布とノイズを測定した結果，家電製品の電源 はその特性から次の 3 種類に分類できることがわかった。

1. 抵抗素子が電力を消費する機器 (ヒーター等)

2. モー夕が負荷の機器（掃除機や冷蔵庫等）

3. DC/DC コンバータを内蔵した機器 (TV・パソコン等)

このうち 1.は純粋な抵抗負荷であり，2.は誘導モー夕負 荷であり純粋な抵抗負荷に近いため, いずれも高周波ノイ ズの発生が少なく電灯線通信に与える影響は少ない。電力 線に重畳されるノイズ発生源として無視できない家電機器 は3.の TV・パソコンのような DC/DC コンバータを内蔵 している機器である。これに対する対策としては, DC/DC コンバータ電源の特性はピーク整流型と呼ばれるものであ り, 電灯線電圧の大きい領域のみを電源として利用してい るため, 電灯線電圧值が小さい領域 $(70 \mathrm{~V}$ 以下) を使用し てデー夕通信を行えば通信への影響が少ないことを確認し た。同時に試作装置での評価で伝送エラー率が $10^{-3}$ 以下で あれば再送によってエラーが十分回復可能であり，それに 対して本装置では伝送速度が遅いことや通信エラーの際に

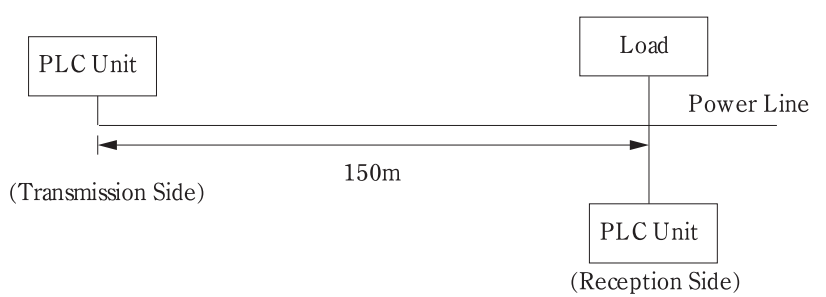

付図 1 実験回路構成図

app. Fig. 1. Examination circuit composition chart.

付表 1 信号伝達試験結果

app. Table 1. Result of signal transmission examination.

\begin{tabular}{|c|c|c|c|c|}
\hline No. & Load & Amount & $\begin{array}{c}\text { Transfer } \\
\text { success rate }\end{array}$ & Group \\
\hline 1 & Personal computer & 4 & $100 \%$ & 3 \\
\hline 2 & Washing machine & 5 & $100 \%$ & 2 \\
\hline 3 & Dryer of clothes & 5 & $100 \%$ & 2 \\
\hline 4 & Printer & 1 & $100 \%$ & 3 \\
\hline 5 & Electric jar & 1 & $100 \%$ & 1 \\
\hline 6 & Refrigerator & 1 & $100 \%$ & 2 \\
\hline
\end{tabular}

は再送信することなどから，伝送速度が 100 bps 時の伝送 エラー率が $10^{-5}$ 以下であることを確認しており，十分問題 ないレベルに達していると考えられる。

これを実証するため，本装置が接続されている電灯線と 同一系統上に上記分類のそれぞれに属する一般家庭で使用 される様々な家電機器を接続し, 家電機器のノイズに対す る電灯線通信装置のロバスト性の検証実験を行った。実験 は，まず付図 1 のように電灯線の一端に送信機を接続し，そ こから $150 \mathrm{~m}$ の位置に受信機と各種家電機器を接続した。 実験は各種家電機器を動作状態にして送信機から信号を 10 回発信し，受信機側で正確に受信できたかどうかを測定し た。付表 1 に使用した家電機器の種類と接続台数と受信成 功率，および上記 3 種類の分類のどれに属するかを示した。 なお，接続台数が複数の場合は，それらは同時に動作させ ている。また，家電機器で電源フィルタ（ノイズ抑制コン デンサ）が電源線側に取り付けられているものとして洗濯 機やパソコンなどが考えられるが，本試験によってこれら の機器が設置されている場合の通信への影響も確認できた。 その結果, いずれの家電機器のノイズに対しても受信成功 率は $100 \%$ で，電灯線通信装置への家電機器のノイズロバ スト性が確認できた。

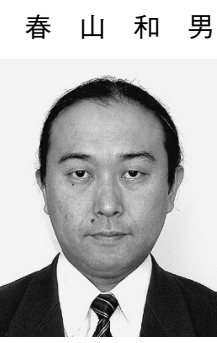

(正員) 1965 年生。1996 年 3 月山口大学工学部 知能情報システム工学科卒業。1994 年宇部工業 高等専門学校電気工学科助手, 現在に至る。現在, 山口大学大学院博士後期課程在学中。 
田中 幹 也 (上級会員) 1952 年生。1982 年 3 月防衛大学校

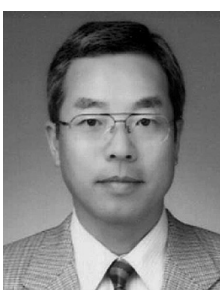
理工学研究科卒業。同校研究員, 1990 年広島電 機大学工学部助教授。1992 年愛媛大学工学部助 教授, 1998 年山口大学工学部教授（電気電子工学 科)，現在に至る。適応・知的制御を中心とした制 御理論およびその応用研究に従事。博士 (工学)。 計測自動制御学会, 日本機械学会, 電子情報通信 学会, IEEE 会員。

小 林 茂 樹 (正員) 1953 年生。1 976 年 3 月大阪工業大学電

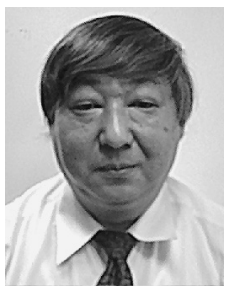

子工学科卒業。同年 4 月 (株) 近計システム入社, 電力関連の計測システムの開発に従事, 2000 年近 計システム退社，現在，有限会社ヴィスト代表取 締役。ネットワーク関連システムの開発に従事。

安 岡 克 典

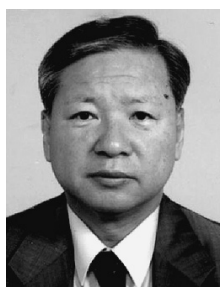

(非会員) 1952 年生。1975 年 3 月成蹊大学法学 部卒。同年 4 月朝日コーポレーション入社，1996 年 12 月退職, 同月介護機器と無線通信機開発, 製造販売の（株）エクセルエンジニアリングを東 京神田にて創業, 代表取締役就任, 1997 年香港, 1998 年米国開発及び営業拠点を設立。在宅用介 護通信機器開発では業界トップ。
内 堀 晃 彦 (正員) 1968 年生。1993 年 3 月信州大学工学部 情報工学科。1995 年信州大学大学院工学系専攻 科博士前記課程情報工学専攻修了。1998 年同博 士後期過程システム開発工学単位修得退学。1998 年山口大学工学部電気電子工学科助手。1 999 年宇 部工業高等専門学校講師, 現在に至る。博士 (工 学)。人工知能, 制御工学に関する研究に従事。

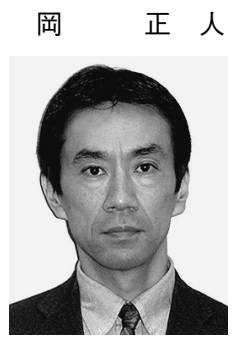

（正員） 1961 年生。1986 年 3 月九州工業大学工 学部第 II 部電気科卒業。2004 年 3 月山口大学 大学院理工学研究科博士後期課程修了。博士（工 学)。1989 年宇部工業高等専門学校機械工学科技 官, 1995 年同助手, 2005 年同助教授, 現在に至 る。超音波モータの制御掞よび医療・福祉に関す る研究に従事。日本機械学会, 日本 AEM 学会各 会員。 